\title{
EXPLORATORY STUDY OF IMPLEMENTING E- BANKING ON CUSTOMER SATISFACTION: EVIDENCE FROM BANK OF MALDIVES
}

\author{
Dr. Ibrahim Sameer \\ Islamic University of Maldives \\ Male' City, Maldives
}

\begin{abstract}
In the bid to adapt to the global developments and to improve the quality of service, banks have invested extensively in ICT (Information and communication technology). In today's competitive market, electronic banking is considered as a new revolution of the traditional banking services which offers customers the greatest convenience for performing banking transactions via electronic. All the banks around the world have gradually increased the number of Internet banking services available to customers and this study focus on the leading commercial banking service provider Bank of Maldives (BML). The aims of this study are to analyzes whether BML implementing e-banking services results in customer satisfaction. This research was based on primary data and have used structured questionnaire in collecting data. The primary data has been collected from sample customers from BML. The data has been analyzed using "Smart PLS 3". The study found that the most important determinant in determining the customer satisfaction of BML is security the most important and reliability the next and also this study found that assurance is not important factor in determining customer satisfaction of BML.
\end{abstract}

Keywords - Technology, Customer Satisfaction, Online Banking and E-banking

\section{INTRODUCTION}

Technology is affecting the lives of every individual in the present age and the rapid expansion of information technology has absorbed into the lives of millions of people and introduced major changes in the worldwide economic and business atmosphere (Orlikowski \& Iacono, 2001 and Tamim, et al., 2011). Technological developments in the banking sector have speeded up communication and transactions for clients and electronic banking is one of the technologies which is swiftly growing banking practice nowadays (Jayawardhena $\&$ Foley, 2000). It is viewed as a supplemental channel used in conjunction with other channels to provide the convenience of banking anytime from one's home or work. Likewise, e-

\author{
Aminath Enas \\ MAPS College, \\ Male' City, Maldives
}

banking eliminates physical and geographical boundaries and time limitations of bank services (Abrol 2014).

Similarly, in a developing country such as the Maldives, adoption of technologically advanced e-banking services are used by major banks. In August 2007, Bank of Maldives (BML) launched the Maldives Internet Banking (MIB) service. This service allows customers to make payments of utility bills and do other related banking transactions through internet $24 \times 7$. Furthermore, e-banking has facilitated many people who are too busy and have no time to visit traditional bank branches and make transactions. Likewise, using ebanking has many advantages for users such as saving time Anguelov et al., 2004 and Auta 2010) and the accuracy of information flow (Liao \& Cheung 2002 and Poon 2008). However, traditional branch-based banking remains as the most used method of making transactions and other related services (Zahir \& Gharleghi 2015).

Banks all over the world invest a lot of money to establish and maintain e-banking services (Chavan 2013). The studies have shown that e-banking acceptance is faced with a lot of challenges and problems (Alam \& Dangarwal 2012 and Chavan 2013). When looking into the Maldivian market, credible online media's (Sun.mv 2014) published news articles about the difficulties and security issues faced by the BML's customers in recent years. It has reported that BML customers are complaining about login issues and account suspensions. In addition, (Mynewsdesk.com 2014) reported and brought public awareness to cases related to a BML fraudulent website to register for Mobile Banking.

Therefore, to compete in the ever-growing technological market, it is vital for BML to transform with the technological advancements of banking operations in the target market. Moreover, BML needs to find new innovative approaches to e-banking, overcome the challenges to strengthen the current services to provide secure e-banking to the customers. As a result, BML can enhance customer satisfaction and maintain the market share to achieve the business objectives.

In the academic world, there have been number of studies (Sathye 1999; Sohail \& Shaikh 2008; Juwaheer, et al., 2012, Cabanillas, et al., 2013 and Mishra \& Vaithianathan 2015) done to find the customer satisfaction level of e-banking. ebanking is changing the whole banking industry, so the aspect 


\section{International Journal of Engineering Applied Sciences and Technology, 2019 Vol. 4, Issue 8, ISSN No. 2455-2143, Pages 38-44 \\ Published Online December 2019 in IJEAST (http://www.ijeast.com)}

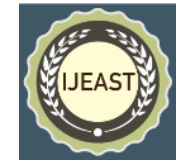

cannot be undermined and need to be researched thoroughly. (Sukkar \& Hassan 2005), argued that information technology models established in developed countries may not be appropriate for less developed countries. Research attention is therefore required on internet banking in the Maldives. The literature review suggests most of the studies has been done on customer satisfaction level of e-banking in countries like India (Singh, Bassi, 2017; Godgeri, Chodankar, 2016), Bangladesh (Hasan, 2015; Islam, Salma, 2014), and Pakistan (Raza, Hassan, 2015; Toor et al., 2016). As per the researcher knowledge much the local context in this discipline has not been explored much. Moreover, to the best of knowledge of the researcher, only one research was conducted in the Maldives related to Internet banking, but the research was not conducted in relation to customer satisfaction (Zahir \& Gharleghi 2015). Likewise, by examining the literature reviews, most of the researchers are in favour of e-banking enhancing customer satisfaction but few researchers were against. Hence, there exists a grey area to be explored by future researchers. To fill in the gap, the present study is launched to determine if customer satisfaction increases through e-banking services of BML in the Maldives. Following are the main objectives of this research:

1. To identify factors that leads to customer satisfaction level of BML with regards to e-banking.

2. To determine the impact that these factors have on overall customer satisfaction of BML.

\section{LITERATURE REVIEW}

\section{A. E-Banking \& Customer Satisfaction}

In this competitive world in order to be market leader organization need to satisfy its customers (Singh \& Kaur 2013). Customer satisfaction is an attitude or feeling that customer had on product/service after been used (Tseng, et al., 2017). A delighted or satisfied customer will make repeat purchase from the company and it leads to word of mouth advertising hence it leads company reputation to go high (Budianto 2019). Therefore, the significance of customer satisfaction on e-banking has become a major area of marketing that has received a considerable publication from practitioners and scholars in the last few decades (Sathye 1999; Sohail \& Shaikh 2008; Juwaheer, et al., 2012, Cabanillas, et al., 2013 and Mishra \& Vaithianathan 2015). Ebanking is a tool with appropriate, accurate and timely utilization which can lead to a successful performance in a competitive world (Munir, et al., 2011). In other words, expanding e-banking should be considered for realizing customer orientation and customer satisfaction.

\section{B. Factors effecting Customer Satisfaction}

The following sections described the main factors of adopting to e-banking services by customers.

\section{Security}

Hoffman et al., (1999) the security factor is the most important factor that leads to e-banking customer satisfaction. In today's world consumer always have questions on how secure the internet platform hence sometimes customers are relectant to used internet platform in making purchase or getting service (Ardakani et al., 2014).

Raza \& Hassan (2015) suggested that in order to determine e-banking customer satisfaction level five characteristics of service quality dimension is important and reveals that tangibility, reliability, responsiveness, and assurance have a significant positive impact on customer satisfaction and also documented that management has to take effective measures to further enhance the security and safety of online bank accounts so that customers can maintain long-term relationships with the usage of online banking. Similarly, (Alam \& Dangarwal 2012) suggest that courtesy, content, timeliness and product and services offered is also important in order to satisfy customer.

Singh \& Bassi (2017) conducted a study in India to identify the customer satisfaction towards e-banking in public and private banks and it reveals that quality e-services help in accomplishing consumer loyalty and creating brand dedication. Furthermore, it also documented that in order to satisfy the needs of the customer's, attractive internet services, proper security concerns and easy to use interface should be provided by the banks to ensure customer satisfaction. In line with this arguments e-banking help organization to attract more customers (Asad et al., 2016), there exist a positive relationship between e-banking and customer satisfaction (Hedayatzadeh et al., 2014 and Musiime \& Ramadhan 2011).

Furthermore, a study conducted in India by (Thirupathi \& Govindaraju2015) reveals that all banks should aim at satisfying the customers' needs by providing maximum features in the services provided. The study noted that security is a key feature in enhancing customer satisfaction in online banking. Overall, the study proves that customers are satisfied with adopting the internet banking and feel comfortable to process the day to day business through the internet banking services.

\section{Reliability}

Reliability can be defined as the ability to performed the promised made by the company in decent manner or in more broad sense how organization promised its customers to deliver its services (Mamilla, et al., 2013).

According to (Palmer et al., 2000 and) the most dominant dimension of service quality in the conventional days was found to be reliability. On the other hand (Wolfinbarger \& Gilly 2001) found that reliability was the strongest and most influential predictor for customer satisfaction for the service industry. In line with this (Omar et al., 2015) stated that most of the empirical studies current days found that reliability is one of the most important factor in determining customer satisfaction in e-industry. Furthermore, Omar suggested that 


\section{International Journal of Engineering Applied Sciences and Technology, 2019 Vol. 4, Issue 8, ISSN No. 2455-2143, Pages 38-44 \\ Published Online December 2019 in IJEAST (http://www.ijeast.com)}

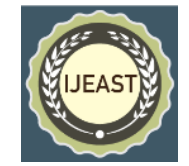

the key attributes of reliability includes accurate delivery, being truthful, keeping the promise, accurate online booking order and website availability. Contrary to this (Udo, et al., 2011) founds that reliability does not play any significant role in determining customer satisfaction.

Toor et al., (2016) conducted a study on customer satisfaction level of e-banking from the banking sector of Pakistan shows that there is a momentous relationship between service quality dimensions and customer satisfaction in E-banking in Pakistan. With more weightage of reliability, responsiveness, and assurance among the five dimensions. Through this study, it can be concluded that service quality in E-banking leads to satisfied customers and thus banks can gain a competitive advantage by offering better-quality services to the customers in today's emulous world.

Similarly, an empirical investigation in Sri Lanka was conducted by (Perera \& Priyanath, 2018) on internet banking service quality on customer satisfaction. The study concludes that contact, efficiency, system availability and compensation will significantly impact on customer satisfaction while fulfillment, privacy, and responsiveness will not significantly impact on the level of the customer satisfaction. Thus, the study extends the knowledge of internet banking service quality amid customer satisfaction by the further inspiring content of service quality dimensions related in the context of internet banking. Moreover, the findings of researchers (Zahir \& Gharleghi, 2015) on Internet banking in the Maldives and the most important determinates conducted in the Maldives found out that performance expectancy and facilitating conditions influence the behavioral intention of using internet banking whereas effort expectancy, social influence and trust does not affect behavioral intention to use internet banking.

\section{Assurance}

Assurance can be defined as the ability (knowledge and courtesy) of employees in delivering excellent service for customer and through that helping company to build trust and confidence for the service provided by the enterprise (Saghier, 2015). According (Parasuraman et al., 1988) assurance is also one of the factor that leads in measuring customer satisfaction of service industry. Udo, et al., (2011) founds that assurance as play significant role in determining customer satisfaction.

Godgeri \& Chodankar (2016) conducted research on customer awareness and satisfaction towards e-banking services, the results suggest that internet banking reduces the time spent in carrying out business activities, reduces congestion in banking halls and improve the delivery system and quick money transferring. However, the study highlighted that along with the world of conveniences this method of banking has a few inherent pitfalls, a special emphasis was given for the security which would improve customer's satisfaction and promote e-banking services to a larger extent. In line of this argument (Islam \& Salma 2014) states that banks need to be aware of future threats to internet banking and introduce new techniques to combat hacking, phishing, pharming and other unethical practices.
Chinedum et al., (2017) founds that e-banking has become a necessary survival weapon and is fundamentally changing the banking industry worldwide and e-banking has changed the way services are delivered by the banking sectors to their customers. Furthermore, they stress that e-banking services have lower operating costs, improved customer services delivery, retained the customer, reduced branch traffics, and downsize the number of branch staff. In line with this reasoning (Parvin \& Hassan 2013) indicated that e-banking services throughout the country are gaining popularity and ebanking customers are increasing because it is comfortable with the digital lifestyle citizen.

When providing e-banking services for the customer by the bank and in order for the customer to get satisfy organization should provide user friendly web portal (Asad et al., 2016 and Gyamfi et al., 2016) and should be creative and innovative creating new products or services and marketing strategies that can stimulate the demand to use internet banking services.

Based on the literature review and evaluation of the topic, it was identified that it is crucial to focus on factors that BML can use to enhance customer satisfaction through e-banking in the Maldives. These factors comprise of reliability, assurance, and security. The model is summarized in Figure 1.

\section{Methodology}

This is quantitative research because this research is used quantitative data in determining customer satisfaction. A structured questionnaire is used based on the literature as the research instrument to collect primary data from the customer of BML. Starting with age \& sex etc, questionnaire comprised of the key questions that determine overall satisfaction level of the customer in using e-banking services. A 5 point Likert scale (From 1 strongly disagree to 5 for strongly agree) will be used.

The population of the research is formed by the e-banking customers of BML. In this research representative sample was used because researchers often believe that a representative sample can be obtained by using a sound judgment, which will result in saving time and money (Black 2010). More than 130 samples were selected and among that 100 samples were selected hence the response rate of sample was $77 \%$. The data has been analyze using SmartPls 3.0 and before conducting the survey to check the reliability of the instrument it was tested and calculated Cronbach's alpha (0.79), which is more than rule of thumb of 0.70 by (Hair et al., 2014).

\section{Regression analysis}

In order to study the impact of these three factors (independent variables) on customer overall satisfaction (dependent variable), regression analysis was used. A following set alternative hypothesis.

H1 - Reliability has a significant positive effect on customer satisfaction in e-banking services of BML 


\section{International Journal of Engineering Applied Sciences and Technology, 2019 Vol. 4, Issue 8, ISSN No. 2455-2143, Pages 38-44 \\ Published Online December 2019 in IJEAST (http://www.ijeast.com)}

H2 - Assurance has a significant positive effect on customer satisfaction in e-banking services of BML.

H3- There is a positive relationship between secure ebanking and customer satisfaction.

\section{Model development}

To test the above set of hypothesis a multivariate regression model was used:

Dependent variable - overall customer satisfaction with eBanking (CS) services (Y).

Independent variables - reliability (X1), security (X2), assurance $(\mathrm{X} 3)$ :

$\mathrm{Y}=\mathrm{a}+\beta_{1} \mathrm{X}_{1}+\beta_{2} \mathrm{X}_{2}+\beta_{3} \mathrm{X}_{3}$

Where:

$\mathrm{Y}=$ overall customer satisfaction with e-banking services of BML.

$\mathrm{a}=$ constant.

$\mathrm{X}_{1}-\mathrm{X}_{3}=$ independent variables.

$\beta_{1}-\beta_{3}=$ slope coefficients.

Hence the proposed model to be tested can be shown as Figure 1.

As shown in Figure 1, it has been hypothesized that overall customer satisfaction with e-banking services are affected by reliability, security, and assurance. For data analysis, SmartPls Version 3 has been used.

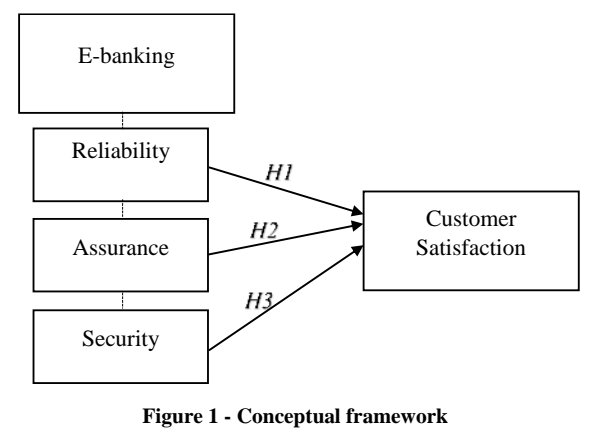

\section{RESULTS AND DISCUSSION}

A total of 16 questions were asked and these questions were specially designed to evaluate BML's internet banking service factors; reliability, assurance and security effect on customer and ultimately determine if the e-banking services of BML enhances customer satisfaction.

Moreover, the participants answered four questions to determine BML's reliability in providing e-banking services to the customers. Likewise, participants answered three questions to determine BML's assurance in providing e-banking services to the customers. Furthermore, participants answered five direct questions to determine if providing secure e-banking leads to customer satisfaction and overall to ensure if BML's ebanking enhances customer satisfaction.

\section{Descriptive Statistics}

Below figure 2 shows PLS Algorithm Test.

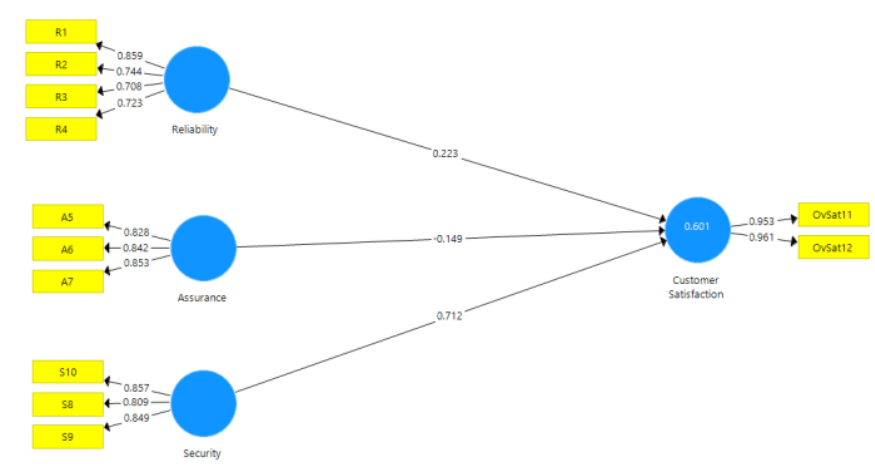

Figure 2 PLS Algorithm Test

Figure 2 indicates that the correlation " $r$ " value, any values that comes near to +1 or -1 relationship get strong. Security, assurance and reliability the " $r$ " values are $0.712,-0.149$ and 0.223 respectively. Relationship between security $(0.712)$ and customer satisfaction strongly positively correlated. Assurance $(-0.149)$ and customer satisfaction has negative weak correlation. Reliability (0.223) and customer satisfaction weakly positively correlated. Furthermore, the coefficient of determination $\left(\mathrm{R}^{2}\right)$ value is $60.1 \%$ which indicates that $60.1 \%$ of the total variation in customer satisfaction of e-banking can be explained by the linear relationship between security, assurance \& reliability.

\section{Bootstrapping Test}

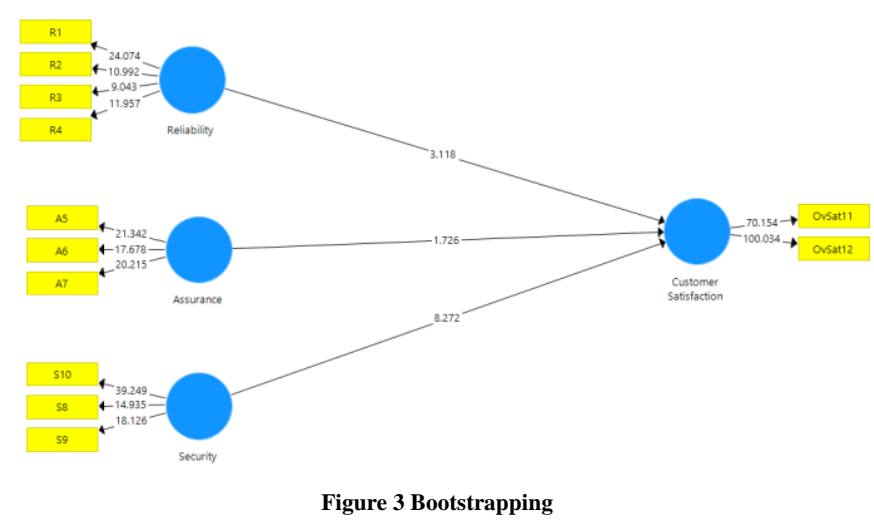

Figure 3 demonstrates that security, assurance and reliability path coefficient values are $8.272,1.726 \& 3.118$ respectively, any value which is less than 1.96 is considered insignificant at $95 \%$ confidence level. The security path coefficient value is 8.272 and is more than 1.96 therefore $\mathrm{H} 1$ is accepted meaning that in order for customer to get satisfied on e-banking services of BLM security is a factor that customer 


\section{International Journal of Engineering Applied Sciences and Technology, 2019 Vol. 4, Issue 8, ISSN No. 2455-2143, Pages 38-44 \\ Published Online December 2019 in IJEAST (http://www.ijeast.com)}

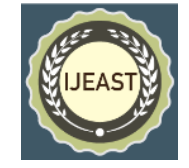

take into account. Assurance path coefficient value is 1.726 and is less than 1.96 therefore null hypothesis is accepted meaning that in order for customer to get satisfied on e-banking services of BLM assurance is not an important factor that customer take into account. Reliability path coefficient value is 3.118 and is more than 1.96 therefore $\mathrm{H} 3$ is accepted meaning that in order for customer to get satisfied on e-banking services of BLM reliability is a factor that customer take into account.

From the above analysis it is clear that security and reliability are positive at $95 \%$ significant level which results in acceptance of H1 \& H3. This results are in line with (Godgeri \& Chodankar, 2016; Islam \& Salma, 2014; Thirupathi \& Govindaraju, 2015; Toor et al., 2016) which documented that providing secure e-banking leads to customer satisfaction, meaning if BML provide safe dependable security platform for its e-banking services will lead to customer satisfaction. This study also found that reliability has significant and positive impact on customer satisfaction and this study is in line with (Raza \& Hassan 2015) suggested that in order to determine ebanking customer satisfaction level reliability have a significant positive impact on customer satisfaction.

Furthermore, the present study found that assurance dimension of e-banking is not statistically significant at $95 \%$ hence accept null hypothesis, indicating assurance dimension of e-banking have no impact on overall customer satisfaction of BML.

From the above analysis it is clear that security was found to be the most significant factor explaining customer satisfaction and then reliability is the next dimension. As BML focused upon the vast advances in innovation and had acquired a stance change in the banking industry in the Maldives to keep the customer satisfied by providing secure e-banking services. In addition, the positive outcomes of security are the result of BML innovative change and the key asset for accomplishing higher effectiveness, control of operations efficiency and gain. Moreover, BML can possibly achieve even better outcomes in the near future if they continually improve the e-banking services.

\section{CONCLUSION \& LIMITATION}

The primary objective of this study is to find out the customer satisfaction towards BML e-banking services. The study found that the most important determinant in determining the customer satisfaction of BML is security the most and reliability the next and also this study found that assurance is not important factor in determining customer satisfaction of BML.

There are some limitations of this study, the first is the exploratory nature of this study by itself and it used convenience sampling and the sample size taken was not that large that may reduce the reliability and generalization of this research therefore future research should focus on more samples. Second this study focus only on the user of e-banking of BML hence non-user voice is not heard through this research therefore future research should take this into account.
Last but not least this study focus on only BML and focus only on Male' city therefore future research should focus more on different bank and more geographical coverage in order to get more valid conclusion.

\section{REFERENCE}

[1] Asad et al., 2016. Prioratizing factors affecting customer satisfaction in the internet banking system based on casue and effect relationships, International conference on applied economics and business, (pp. 210-219).

[2] Abrol, 2014. Impact of Internet banking on customer satisfaction and business performance. Impact of Internet banking on customer satisfaction and business performance: A conceptual analysis, (pp. 1-233).

[3] Alam \& Dangarwal, 2012. Internet banking customer satisfaction and online banking attributes. Indian journal of applied research, 1(6), (pp. 198-199).

[4] Ali et al., 2015. Measuring customer satisfaction of ebanking in Bangladesh. Development Compilation, 11(1), (pp.104-116)

[5] Anguelov, C. E., Hilgert, M. A. \& Hogarth, J. M., 2004. US consumers and electronic banking 1995-2003. Fed. Res. Bull, Volume 90, (pp. 1).

[6] Ardakani, D. A., Moradi, H. \& Kafash, M. H., 2014. Factors affecting customer confidence in using Ebanking. European Online Journal of Natural and Social Sciences: Proceedings, 2(3), (pp. 2769-2776).

[7] Auta , E. M., 2010. E-Banking in developing economy: empirical evidence from Nigeria. Journal of applied quantitative methods, 5(2), (pp. 212-222).

[8] Black, 2010. Purposive sampling. [Online], Available at: https://research-methodology.net/sampling-in-primarydata-collection/purposive-sampling/ [Accessed 22 June 2019].

[9] Budianto, A., 2019. Customer Loyalty: Quality of Service. Journal of Management Review, 3(1), (pp. 299305).

[10] Cabanillas, L., Francisco, M. \& Guardia, F. R., 2013. The determinants of satisfaction with e-banking. Industrial Management \& Data Systems, 113(5), (pp. 750-767).

[11] Chavan, J., 2013. Internet banking-benefits and challenges in an emerging economy. International Journal of Research in Business Management, 1(1), (pp. 19-26).

[12] Chinedum et al., 2017. Effects of e-banking services delivery on customer satisfaction in select banks in Anambra state - Nigeria, Journal of advance management research, 5(4), (pp. 289-310).

[13] Galetto, 2018. How banks can improve the customer experience: 5 tips and best practices. [Online]

[14] Available at: https://www.ngdata.com/how-banks-canimprove-customer-experience/ [Accessed 11 May 2019]. 


\section{International Journal of Engineering Applied Sciences and Technology, 2019 Vol. 4, Issue 8, ISSN No. 2455-2143, Pages 38-44 \\ Published Online December 2019 in IJEAST (http://www.ijeast.com)}

[15] Godgeri \& Chodankar, 2016. A study on customer awareness and satisfaction towards e-banking services, (pp. 1-16).

[16] Gyamfi et al., 2016. Effect of interent banking service quality on cusotmer satisfaction: Evidence from Ghanaian Banking industry, Research journal of Social science and management, 3(4), (pp. 1-14).

[17] Hair, J. F., Black, W. C., Babin , B. J. \& Anderson, R. E., 2014. Multivariate Data Analysis. 7th Edition ed. Edinburgh: Pearson Education Limited.

[18] Hasan, 2015. Online and internet banking and its effect on customer satisfaction (Focus on "Online and internet banking users" of Brac Bank Limited. (pp. 1-46) 37.

[19] Hedayatzadeh et al., 2014. E-banking analysis and its role in customer satisfaction and attraction (A case study on E.Nbank of Urmia city). International Journal of Research and Reviews in Applied Sciences, 21(3), (pp.131-143).

[20] Hoffman, D. L., Novak, T. P. \& Peralta, M., 1999. Building consumer trust online. Communications of the ACM, 42(4), (pp. 80-85).

[21] Islam \& Salma, 2014. Customer satisfaction of internet banking in Bangladesh: A case study on Citibank N.A. Asian journal of applied science and engineering, 3(1), (pp. 3-12).

[22] Jayawardhena, C. \& Foley, P., 2000. Changes in the banking sector - the case of Internet banking in the UK. Internet Research, 10(1), (pp. 19-31).

[23] Juwaheer, D., Pudaruth, S. \& Ramdin, P., 2012. Factors influencing the adoption of internet banking: a case study of commercial banks in Mauritius. World Journal of Science, Technology and Sustainable Development, 9(3), (pp. 204-234).

[24] Kim, C. and Mauborgne, R., 2004. Blue Ocean Strategy. [Online] Available at: www.blueoceanstrategy.com [Accessed 2019 May 09].

[25] Liao, Z. \& Cheung, M. T., 2002. Internet-based e-banking and consumer attitudes: an empirical study. Information \& Management, 39(4), (pp. 283-295).

[26] Mamilla, R., Janardhana , G. \& Babu , A. G., 2013. Customer Satisfaction on Reliability Dimension of Service Quality in Indian Higher Education. International Journal of Industrial and Manufacturing Engineering, 7(12), (pp. 3210-3215).

[27] Mishra, V. \& Vaithianathan, S., 2015. Customer personality and relationship satisfaction: Empirical evidence from Indian banking sector. International Journal of Bank Marketing, 33(2), (pp. 122-142).

[28] Munir, R., Perera, S. \& Baird, K., 2011. An Analytical Framework to Examine Changes in Performance Measurement Systems within the Banking Sector. Australasian Accounting, Business and Finance Journal, 5(1), (pp. 93-115).
[29] Musiime \& Ramadhan, 2011. African journal of marketing management. Internet banking, customer adoption and customer satisfaction, pp. 8-9.

[30] mynewsdesk.com, 2014. Phishing Fraud (Maldives Mobile Banking). [Online]

[31] Available at: http://www.mynewsdesk.com/mv/bankofmaldives/pressre leases/phishing-fraud-maldives-mobile-banking-1043407

[32] [Accessed 8 March 2019].

[33] Omar, H. F. H., Saadan, K. B. \& Seman, K. B., 2015. Determining the Influence of the Reliability of Service Quality on Customer Satisfaction: The Case of Libyan ECommerce Customers. International Journal of Learning \& Development, 5(1), (pp. 86-89).

[34] Orlikowski, W. J. \& Iacono, C. S., 2001. Research commentary: Desperately seeking the "IT" in IT research-A call to theorizing the IT artifact. Information systems research, 12(2), (pp. 121-134).

[35] Palmer, J. W., Bailey, J. P. \& Faraj, S., 2000. The Role of Intermediaries in the Development of Trust on the Www: the Use and Prominence of Trusted Third Parties and Privacy Statements. Journal of Computer-Mediated Communication, 5(3). (pp.JCMC532)

[36] Parasuraman, A., Zeithaml, V. A. \& Berry, L. L., 1988. Servqual: A multiple-item scale for measuring consumer perception of service quality. Journal of retailing, 64(1), (pp. 12).

[37] Parvin \& Hassan, 2013. Customer satisfaction of ebanking in Bangladesh with focus on Dutch Bangla Bank Ltd: The context of twenty first century, International journal of research in computer application and management, 3(5), (pp. 83-90).

[38] Perera \& Priyanath, 2018. Impact of internet banking service quality on customer satisfaction: an empirical investigation of customers in Sri Lanka, International journal of management, IT and Engineering, 8(2), (pp. 1819).

[39] Poon, W., 2008. Users' adoption of e-banking services: the Malaysian perspective. Journal of Business \& Industrial Marketing, 23(1), (pp. 59-69).

[40] Raza \& Hassan, 2015. Internet banking and customer satisfaction in Pakistan. Internet banking and customer satisfaction in Pakistan, 7(1), (pp.24-36).

[41] Saghier, N. M. E., 2015. Managing Service Quality: Dimensions of service quality: a study in Egypt. International Journal of African and Asian Studies, Volume 9, (pp. 56-63).

[42] Sathye, M., 1999. Adoption of Internet banking by Australian consumers: an empirical investigation. International Journal of Bank Marketing, 17(7), (pp. 324334). 


\section{International Journal of Engineering Applied Sciences and Technology, 2019 Vol. 4, Issue 8, ISSN No. 2455-2143, Pages 38-44 \\ Published Online December 2019 in IJEAST (http://www.ijeast.com)}

[43] Seyal \& Rahim, 2011. Customer satisfaction with internet banking in Brunei Darussalam: evaluating the role of demographic factors. A Journal of Electronic Services in the Public and Private Sectors, 7(3), (pp.47-68).

[44] Siddik \& Selvachandra, 2011. A study on customer satisfaction towards E-banking services of ICIC Bank in Chennai city. International Journal of Engineering and Management Research, 1(4), (pp. 1-18).

[45] Simon \& Senaji, 2016. Effect of electronic banking on customer satisfaction in selected commercial banks, Kenya. International Academic Journal of Human Resource and Business Administration, 2(2), (pp. 41-63).

[46] Singh \& Bassi, 2017. A review on customer satisfaction with internet banking in public and private bank, International journals of engineering sciences and research technology, 6(3), (pp. 270-275).

[47] Singh, J. \& Kaur, P., 2013. Customers' attitude towards technology based services provided by select Indian banks: Empirical analysis. International Journal of Commerce and Management, 23(1), (pp. 56-68).

[48] Sohail, M. S. \& Shaikh, N. M., 2008 . Internet banking and quality of service: Perspectives from a developing nation in the Middle East. Online Information Review, 32(1), (pp. 58-72).

[49] Sukkar \& Hassan, 2005. Toward a model for the acceptance of Internet banking in developing countries. Information Technology for Development, 11(4), (pp.381-398).

[50] Sun.mv, 2014. Complaints rife following BML internet banking upgrade. [Online]

[51] Available at: https://english.sun.mv/16804 [Accessed 8 March 2019].

[52] Tamim, R. M. et al., 2011. What Forty Years of Research Says About the Impact of Technology on Learning : A Second-Order Meta-Analysis and Validation Study. Review of Educational Research, 81(1), (pp. 4-28).

[53] Thirupathi \& Govindaraju, 2015. A study on customer satisfaction of Internet banking with reference to Salem City. International Journal of Innovations in Engineering and Management, 4(1), (pp. 6-12).

[54] Toor et al., 2016. The impact of e-banking on customer satisfaction: Evidence from banking sector of Pakistan. Journal of Business Administration Research, 5(2), (pp.27-40).

[55] Tseng, S.-M., Wu, J.-R., Wei Chou, C. \& Tsai, H.-L., 2017. A study on Consumer Evaluations of Continued Group-Buying Intentions. International Journal of Innovative Science, Engineering \& Technology, 4(6), (pp. 356-366).

[56] Udo, G. J., Bagchi, K. K. \& Kirs, P. . J., 2011. Using SERVQUAL to assess the quality of e-learning experience. Computers in Human Behavior, 27(3), (pp. 1272-1283).

[57] Vasista, 2013. The effect of internet banking service quality on customer satisfaction in Riyadh, Saudi Arabia. Journal of Business Administration, 2(3), (pp.112-136).

[58] Wolfinbarger, M. \& Gilly, M., 2001. Shopping online for freedom, control, and fun. California management review, 43(2), (pp. 34-55).

[59] Zahir \& Gharleghi, 2015. Adoption of internet banking in Maldives, the most important determinates. sian Social Science, 11(2), (pp.181-189). 